RASĀYAN J. Chem.

Vol. 13 | No. 3 |1817-1823| July - September | 2020 ISSN: 0974-1496 | e-ISSN: 0976-0083 | CODEN: RJCABP

\title{
BIOACTIVE COMPOUNDS FROM A MARINE SPONGE DERIVED FUNGUS Penicillium oxalicum WR3
}

\author{
D. Handayani ${ }^{1, *}$, R. Amilia ${ }^{1}$, I. Aminah ${ }^{1}$, T. Hertiani ${ }^{2}$, N. P. Ariantari ${ }^{3,4}$ \\ and P. Proksch ${ }^{3}$ \\ ${ }^{1}$ Laboratory of Sumatran Biota/Faculty of Pharmacy, Universitas Andalas, \\ Padang 25163, Indonesia \\ ${ }^{2}$ Faculty of Pharmacy, Universitas Gadjah Mada, Sekip Utara, Yogyakarta 55281, Indonesia \\ ${ }^{3}$ Institut für Pharmazeutische Biologie und Biotechnologie, Heinrich-Heine-Universität \\ Düsseldorf, Universitätsstrasse 1, 40225 Düsseldorf, Germany \\ ${ }^{4}$ Department of Pharmacy, Faculty of Mathematics and Natural Sciences, Udayana University, \\ 80361 Bali, Indonesia \\ * E-mail: dianhandayani@phar.unand.ac.id
}

\begin{abstract}
Chromatographic workup on ethyl acetate extract of fungus culture, Penicillium oxalicum WR3, isolated from the marine sponge Haliclona fascigera, collected from Mandeh Island, south coast of West Sumatera, Indonesia, resulted in the isolation of two known fungal metabolites, culvularin (1) and sydowinin B (2). These compounds were evaluated for the antibacterial towards Staphylococcus aureus and methicillin-resistant Staphylococcus aureus (MRSA), as well as cytotoxic activities against Hela, T47D, and WiDR cell lines. Based on the results of the antibacterial assay, both compounds revealed relatively weak inhibition towards both tested bacterial strains when treated at a concentration of $125 \mu \mathrm{g} / \mathrm{disc}$ and $500 \mu \mathrm{g} / \mathrm{disc}$, respectively. Furthermore, compound $\mathbf{1}$ showed mild cytotoxicity against the human cancer cell lines, T47D and HeLa, with $\mathrm{IC}_{50}$ values of $142.66 \mathrm{ppm}$ and $164.88 \mathrm{ppm}$, respectively.

Keywords: Penicillium oxalicum, Halicona fascigera, Antibacterial, Cytotoxic, Culvularin, Sydowinin B.
\end{abstract}

(C) RASĀYAN. All rights reserved

\section{INTRODUCTION}

The sponge is one of the abundant marine organisms in Indonesia. Based on the Snellius-II expedition, there are 830 types of marine sponges found in western Indonesia. ${ }^{1}$ The sponge is also known as a very fertile host for a variety of microorganisms. Microbial symbionts can be either bacterial or fungal and contribute over $40-70 \%$ of the animal biomass and produce secondary metabolites. ${ }^{2,3}$ In particular, marine sponge-derived fungi have attracted attention for their production of structurally unique molecules with intriguing bioactivities. ${ }^{4}$ Examples include the antibacterial bisabolane-type sesquiterpenoids from sponge-associated fungus, Aspergillus sp., as well as the novel and potent antimycobacterial compounds, trichoderins A, A1, and B, isolated from marine sponge-derived fungus, Trichoderma $\mathrm{sp.} .{ }^{5}$ Recently, we have examined several fungi from marine sponges and mangrove plants from West Sumatra, Indonesia, which show their ability to produce antibacterial and cytotoxic compounds, including Aspergillus nomius NC06, Cocliobolus geniculatus WR12 and Diaporthe amygdali SgKB4..$^{6-8}$

As part of our continuous research for bioactive molecules from the marine sponge-derived fungi, we investigate Penicillium oxalicum WR3, a fungus associated with the marine sponge Haliclona fascigera. The sponge, H. fascigera, was found in Mandeh Island, south coast of West Sumatera, Indonesia. Preliminary studies on ethyl acetate extract of $P$. oxalicum WR3 showed its potential for antibacterial and cytotoxic activities. ${ }^{9,10}$ In the current study, we present details of the isolation, and structure identification of two metabolites, curvularin (1) and sydowinin B (2) isolated from ethyl acetate extract of $P$. oxalicum WR3, as well as, their antibacterial and cytotoxic activities.

Rasayan J. Chem., 13(3), 1817-1823(2020)

http://dx.doi.org/10.31788/ RJC.2020.1335549

CrossMark 
RASĀYAN J. Chem.

Vol. 13 | No. 3 |1817-1823| July - September | 2020

\section{General Experimental Procedures}

\section{EXPERIMENTAL}

Organic solvents are distilled before being used for extraction and chromatography. Solvents for spectrophotometry were obtained from Merck ${ }^{\circledR}$. Fungal growth media Sabouraud Dextrose Agar (SDA) $\left(\operatorname{Merck}^{\circledR}\right)$, Bacteria growth media Nutrient Agar (NA) $\left(\operatorname{Merck}^{\circledR}\right)$, a disk of chloramphenicol (BD BBL ${ }^{\mathrm{TM}}$ ) and a disk of nystatin $\left(\mathrm{Oxoid}^{\circledR}\right)$. Fractions were monitored on TLC silica gel $60 \mathrm{~F}_{254 \mathrm{~nm}}\left(\mathrm{Merck}^{\circledR}\right)$ and visualized under $U_{\lambda 254 \mathrm{~nm}}$ and $\mathrm{UV}_{\lambda 365 \mathrm{~nm}}$. Open column chromatography was carried out on Silica gel 60 $(0.040-0.005 \mathrm{~mm})$ Merck $^{\circledR}$ (Darmstadt, Germany) and Gel filtration on sephadex ${ }^{\mathrm{TM}} \mathrm{LH}-20$ (GE healthcare ${ }^{\circledR}$ ). Melting points were measured using the Innotech ${ }^{\circledR}$ Melting Point Apparatus. A Perkin-Elmer Spectrum One FT-IR instrument used for the experimental IR spectrum. The Ultraviolet spectrum was recorded on Shimadzu ${ }^{\circledR}$ ultraviolet-visible Pharmaspec 1700 spectrometer. 1D and 2D NMR spectra were recorded on Bruker AVANCE DMX 600 and 300 NMR spectrometers. The chemical shifts were referred to residual solvent signals at $\delta_{\mathrm{H}} 2.50\left(\mathrm{DMSO}-d_{6}\right)$ for ${ }^{1} \mathrm{H}$ and $\delta_{\mathrm{C}} 39.5\left(\mathrm{DMSO}-d_{6}\right)$ for ${ }^{13} \mathrm{C}$. Mass spectrum (ESI) was measured with a Finnigan LCQ Deca mass spectrometer and the HRESIMS spectrum was recorded with an FTHRMS-Orbitrap (Thermo-Finnigan) mass spectrometer.

\section{Fungal Material}

The marine-derived fungus $P$. oxalicum WR3 was isolated from marine sponge $H$. fascigera. The marine sponge was collected from Mandeh Island, South Coast of West Sumatera, Indonesia. The fungus was grown in Sabouraud Dextrose Agar (SDA) media and incubated at $25^{\circ} \mathrm{C}$ for 4-7 days. ${ }^{10}$

\section{Identification of Fungal Cultures}

Fungal cultures were identified according to a molecular biology protocol by DNA amplification and sequencing of the ITS region as described previously. ${ }^{10}$ The fungal strain was identified as Penicillium oxalicum. A voucher strain (strain designation WR3) is kept in the Laboratory of Sumatra Biota/Faculty of Pharmacy, Andalas University, Padang, Indonesia.

\section{Cultivation}

The fungus was grown in twenty Erlenmeyer flasks $(1 \mathrm{~L}$ each) containing $100 \mathrm{~g}$ of rice and $110 \mathrm{~mL}$ of distilled water at room temperature $\left(25^{\circ} \mathrm{C}\right)$ for 40 days..$^{11}$

\section{Extraction and Fractionation}

The secondary metabolites which are produced by $P$. oxalicum WR3 were extracted with EtOAc. The EtOAc extract was then evaporated with a rotary evaporator and partitioned between $n$-hexane and $90 \% \mathrm{MeOH}$.The $90 \% \mathrm{MeOH}$ fraction $(5.7 \mathrm{~g}$ ) was chromatographed on Sephadex LH-20 column with $100 \% \mathrm{MeOH}$ as a solvent, to yield five subtraction. Subfraction IV (3.9 g) was further chromatographed over silica gel using $n$-hexane: EtOAc and EtOAc: $\mathrm{MeOH}$ as solvent systems. Based on detection by TLC using EtOAc: DCM $(20: 80)$ as a solvent system, collected fractions were combined. Two fractions were recrystallized, to afford compounds $1(1124.5 \mathrm{mg}$ ) and $\mathbf{2}(164.2 \mathrm{mg})$.

\section{MIC Assay Test for Antibacterial Activity}

For the MIC (Minimum Inhibitory Concentration) assay of antibacterial activity, the antibacterial activity of compounds 1 and 2 was tested against S. aureus and methicillin-resistant Staphylococcus aureus (MRSA) using the agar diffusion method. DMSO and chloramphenicol $(30 \mu \mathrm{g} / \mathrm{disc})$ were used as a negative and positive control, respectively. The paper disc placed on the surface of Nutrient Agar medium containing $10^{5}$ of tested bacteria and incubated at $37^{\circ}$ for 24 hours. The lowest concentration contained a clear zone around the paper disc was described as a minimum inhibitory concentration (MIC) value. ${ }^{6}$

\section{MTT Assay Test for Cytotoxic Activity}

The isolated compounds were tested on HeLa (cervix cell line), WiDr (colon adenocarcinoma cell line), T47D (human ductal breast epithelial tumor cell line) and Vero (normal cell line) using MTT assay ${ }^{12}$. All compounds were tested in the Laboratory of Parasitology, Gadjah Mada University. 
RASĀYAN J. Chem.

Vol. 13 | No. 3 |1817-1823| July - September | 2020

\section{RESULTS AND DISCUSSION}

Based on the amplified PCR of the 18S rRNA gene showed that DNA bands were obtained at $978 \mathrm{bp}$. A BLAST search on the NCBI gene deposit showed that WR3 isolate had a maximum identity of $99 \%$ with P. oxalicum strain 114-2. According to Meusemann, et al. $(2010)^{13}$, microorganisms with differences less than $2 \%$ or similarity more than $97 \%$ of $18 \mathrm{~S}$ rRNA, could be concluded as identical species.

The phylogenetic tree constructed using a neighbor-joining method with a bootstrap value of 1000 . The analysis results showed that tree formation consists of one clade. The clade was a group of Penicillium. The WR3 isolate gave $100 \%$ identity to $P$. oxalicum, thus confirmed the identification result (Fig.-1).

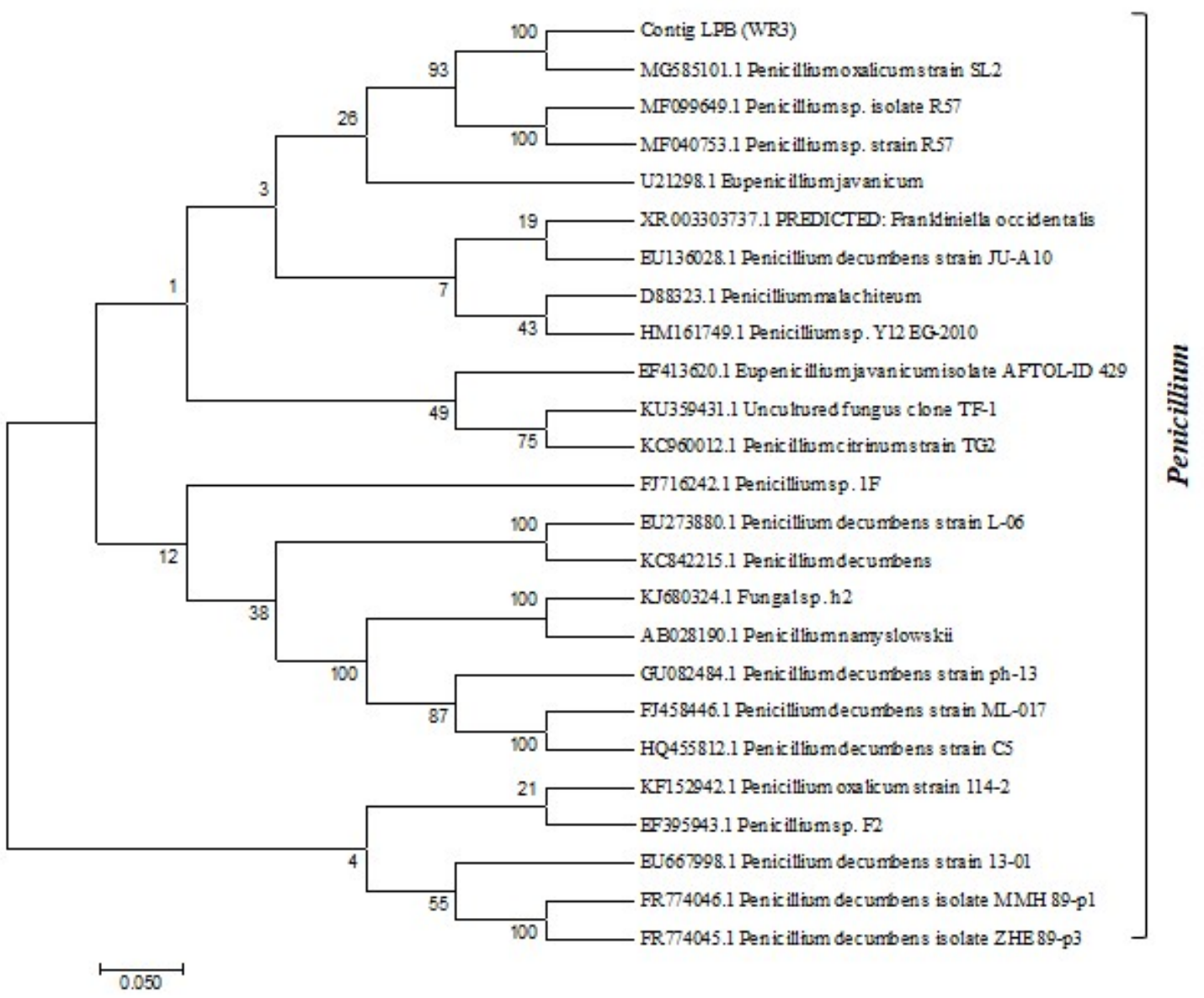

Fig.-1: The Phylogenetic Tree Using the Neighbor-joining Method of the 18S rRNA Gene Sequence From the Fungi isolate WR3 derived Marine Sponge Haliclona fascigera and Some Strain of Penicillium. The Scale Bar indicates a 0.05 substitution Nucleotide Position

Compound $1(1124.5 \mathrm{mg})$ was isolated as colorless crystals, $\mathrm{mp} 203.3 \sim 203.9^{\circ} \mathrm{C}$. The HRESIMS spectrum of 1 showed a prominent pseudomolecular ion peak at $\mathrm{m} / z 293.1384[\mathrm{M}+\mathrm{H}]^{+}$, attributed to the molecular formula $\mathrm{C}_{16} \mathrm{H}_{20} \mathrm{O}_{5}$, corresponding to seven degrees of unsaturation. UV absorptions with $\lambda_{\max }$ in methanol at 302.8 and $271.1 \mathrm{~nm}$ were indicative of aromatic functionality with extended conjugation. The IR spectrum of 1 showed absorption bands for $\mathrm{OH}$ group at 3536.5 and $3269.5 \mathrm{~cm}^{-1} ; \mathrm{CH}_{2}$ at 2934.6 and $1691.1 \mathrm{~cm}^{-1} ; \mathrm{C}=\mathrm{C}$ aromatic at $1598.7 \mathrm{~cm}^{-1}$; and C-C at $999.3 \mathrm{~cm}^{-1}$. The ${ }^{1} \mathrm{H}$ NMR data of $\mathbf{1}$ (Table-1) displayed signals of two aromatic protons in meta-position, six sets of methylene, one oxygenated methine and, one methyl group. Moreover, ${ }^{13} \mathrm{C}$ NMR revealed the signals of two carbonyls and four $\mathrm{sp}^{2}$ carbons, of which two were oxygenated ones. Analysis of 2D NMR in combination with HRESIMS data of $\mathbf{1}$, showed a good agreement with those reported in the literature for curvularin ${ }^{14}$. Hence, the structure of $\mathbf{1}$ was concluded to be identical 
RASĀYAN J. Chem.

Vol. 13 | No. 3 |1817-1823| July - September | 2020

to culvularin (Fig.-2). Curvularin, a macrocyclic lactone, was repeatedly reported from numerous fungal species belonging to the genus Penicillium, ${ }^{15,16}$ Curvularia, ${ }^{11}$ and Alternaria. ${ }^{17}$

Compound $2(164.2 \mathrm{mg})$ was obtained as yellow needle crystals, $\mathrm{mp} 155.5 \sim 157.2^{\circ} \mathrm{C}$. The molecular formula of 2 was deduced as $\mathrm{C}_{16} \mathrm{H}_{12} \mathrm{O}_{7}$, through analysis of its HRESIMS spectrum, requiring eleven degrees of unsaturation. The UV spectrum of 2 showed absorptions at $\lambda_{\max } 382.8,293.6,264.4$, and $237.2 \mathrm{~nm}$. The IR spectrum of 2 showed absorption bands for $\mathrm{OH}$ group at $3403.2 \mathrm{~cm}^{-1} ; \mathrm{C}=\mathrm{O}$ at $1640.6 \mathrm{~cm}^{-1}$ and $\mathrm{C}=\mathrm{C}$ aromatic at $1056.3 \mathrm{~cm}^{-1}$. Investigation of 1D/2D NMR data of 2 (Table-2) revealed signals of two aromatic protons characteristic for 1,2,3,4-tetrasubstituted benzene, two aromatic singlets, one set of oxygenated methylene and one methoxy group, in addition to two carbonyl carbons and eight $\mathrm{sp}^{2}$ hybridized carbons including four oxygenated ones. A comparison of its NMR data with those of published data for sydowinin B showed both compounds were identical ${ }^{18}$. Therefore, the structure of $\mathbf{2}$ was identified as sydowinin B (Fig.-2). This compound was initially found as a metabolite of Aspergillus sydowii more than thirty years ago ${ }^{19}$. Subsequent studies reported it from some species of marine-derived fungi, such as A. sydowii PSU-F 154, ${ }^{20}$ Engyodontium album DFFSCS021, ${ }^{21}$ Aspergillus sp. SCSIO Ind09F01, ${ }^{22}$ Scopulariopsis sp. $^{23}$ and, Arthrinium sp. ${ }^{23}$ as well as from fungal endophyte Penicillium citrinum. ${ }^{25}$

Table-1: The ${ }^{1} \mathrm{H}$ and ${ }^{13} \mathrm{C}$ NMR Data of Compound 1 in DMSO- $d_{6}$

\begin{tabular}{c|c|c}
\hline No. & ${ }^{13} \mathrm{C}\left(\delta_{\mathrm{C}}\right.$ in $\left.\mathrm{ppm}\right)$ & ${ }^{1} \mathrm{H}\left(\delta_{\mathrm{H}}\right.$ in ppm, $J$ in Hz $)$ \\
\hline 1 & 170.2 & - \\
\hline 2 & 38.7 & $3.71, \mathrm{~d}(15.6)$ \\
\hline 3 & 135.2 & - \\
\hline 4 & 110.9 & $6.17, \mathrm{~d}(2.3)$ \\
\hline 5 & 159.1 & - \\
\hline 6 & 101.6 & $6.27, \mathrm{~d}(2.3)$ \\
\hline 7 & 157.3 & - \\
\hline 8 & 119.6 & - \\
\hline 9 & 206.0 & $2.98, \mathrm{ddd}(15.6,8.8,2.5)$ \\
\hline 10 & 42.9 & $1.63, \mathrm{~m}$ \\
& 22.3 & $1.45, \mathrm{~m}$ \\
\hline 11 & 26.2 & $1.18, \mathrm{~m}$ \\
\hline 12 & 23.3 & $1.35, \mathrm{~m}$ \\
& & $1.20, \mathrm{~m}$ \\
\hline 13 & 31.6 & $1.37, \mathrm{~m}$ \\
& 71.4 & $1.54, \mathrm{~m}$ \\
\hline 14 & 20.1 & $1.07, \mathrm{~d}(6.3)$ \\
\hline 15 & - & $9.94, \mathrm{~s}$ \\
\hline 16 & - & $9.75, \mathrm{~s}$ \\
\hline $7-\mathrm{OH}$ & &
\end{tabular}

Compounds $\mathbf{1}$ and $\mathbf{2}$ were subjected to biological assays for antibacterial activity against $S$. aureus, and MRSA (Tabel-3). They showed low antibacterial activity against S. aureus with MICs of 125 and 500 $\mu \mathrm{g} / \mathrm{disc}$ and MRSA with MIC values of 250 and $500 \mu \mathrm{g} / \mathrm{disc}$, respectively. Culvularin showed better antibacterial activity than sydowinin B. All isolated compounds were evaluated for their cytotoxicity against three cancer cell lines (Table-4). Culvularin had better cytotoxic activity against all cell lines including normal cell lines (Vero) than sydowinin B. 
RASĀYAN J. Chem.

Vol. 13 | No. 3 |1817-1823| July - September | 2020

Based on literature studies, it is known that curvularin is a macrolide antibiotic produced by many fungal species from several genera, among which Curvularia, Penicillium, and Alternaria. This compound can inhibit the activity of protein 90 (HSP90). HSP90 is a chaperone that is involved in cell signaling, proliferation, and survival. ${ }^{26}$ Therefore, curvularin is a promising compound in treating cancer, as well as potential antibiotics. ${ }^{27}$

Table-2: Comparison of ${ }^{1} \mathrm{H}$ and ${ }^{13} \mathrm{C}$ NMR Data of Compound 2, with those reported for Sydowinin B (DMSO- $d_{6}$ )

\begin{tabular}{|c|c|c|}
\hline No. & ${ }^{13} \mathrm{C}\left(\delta_{\mathrm{C}}\right.$ in $\left.\mathrm{ppm}\right)$ & ${ }^{1} \mathrm{H}\left(\delta_{\mathrm{H}}\right.$ in $\mathrm{ppm}, J$ in $\left.\mathrm{Hz}\right)$ \\
\hline 1 & 117.2 & - \\
\hline 2 & 148.9 & - \\
\hline 3 & 125.4 & $7.47, \mathrm{~d}(9.1)$ \\
\hline 4 & 120.2 & $7.63, \mathrm{~d}(9.1)$ \\
\hline $4 a$ & 150.7 & - \\
\hline $4 \mathrm{~b}$ & 155.5 & - \\
\hline 5 & 103.9 & $6.99, \mathrm{~d}(1.3)$ \\
\hline 6 & 154.1 & - \\
\hline 7 & 107.1 & $6.74, \mathrm{~d}(1.3)$ \\
\hline 8 & 160.4 & - \\
\hline $8 \mathrm{a}$ & 106.6 & - \\
\hline 9 & 180.3 & - \\
\hline $9 \mathrm{a}$ & 117.0 & - \\
\hline 10 & 166.6 & - \\
\hline 11 & 52.2 & $3.85, \mathrm{~s}$ \\
\hline 12 & 62.4 & $4.59, \mathrm{~d}(6.0)$ \\
\hline $2-\mathrm{OH}$ & - & $10.40, \mathrm{~s}$ \\
\hline $8-\mathrm{OH}$ & - & $12.20, \mathrm{~s}$ \\
\hline $12-\mathrm{OH}$ & - & $5.52, \mathrm{t}(6.0)$ \\
\hline
\end{tabular}<smiles>CO[C@H](C)CCCC=CC(=O)c1c(O)cc(O)cc1CC(=O)O</smiles>

Curvularin (1)<smiles>COC(=O)c1c(O)ccc2oc3cc(CO)cc(O)c3c(=O)c12</smiles>

Sydowinin B (2)

Fig.-2: Structures of Isolated Compounds from P. oxalicum WR3

Table-3: Antibacterial Activities of Culvularin and Sydowinin B from P. oxalicum WR3

\begin{tabular}{c|c|c|c|c}
\hline \multirow{2}{*}{$\begin{array}{c}\text { The concentration } \\
\text { of the compound } \\
(\mu \mathrm{g} / \text { disc })\end{array}$} & \multicolumn{3}{|c}{ Inhibition Zones $(\mathrm{mm}) \pm$ Standard Deviation (SD) } \\
\cline { 2 - 5 } & \multicolumn{2}{|c}{ S.aureus } & \multicolumn{2}{c}{ MRSA } \\
\cline { 2 - 5 } & Curvularin & Sydowinin B & Culvularin & Sydowinin B \\
\hline 500 & $7.88 \pm 0.04$ & $7.88 \pm 0.04$ & $7.33 \pm 0.04$ & $7.28 \pm 0.04$ \\
\hline 250 & $7.18 \pm 0.04$ & - & $7.23 \pm 0.04$ & - \\
\hline 125 & $6.48 \pm 0.11$ & - & - & - \\
\hline 62.5 & - & - & - & - \\
\hline
\end{tabular}


RASĀYAN J. Chem.

Vol. 13 | No. 3 |1817-1823| July - September | 2020

Table-4: $\mathrm{IC}_{50}$ Values of the isolated Compounds from P. oxalicum WR3 against Cancer Cell Lines and Vero Cell Line

\begin{tabular}{c|c|c|c|c}
\hline Compound & T47D $(\mu \mathrm{g} / \mathrm{ml})$ & HeLa $(\mu \mathrm{g} / \mathrm{ml})$ & $\begin{array}{c}\text { WiDR } \\
(\mu \mathrm{g} / \mathrm{ml})\end{array}$ & Vero $(\mu \mathrm{g} / \mathrm{ml})$ \\
\hline Culvularin (1) & 142.7 & 164.9 & 208.8 & 210.2 \\
\hline Sydowinin B (2) & 454.5 & $>100$ & 557.8 & $>100$ \\
\hline Doxorubicin (positive control) & 33.5 & 19.2 & 15.1 & 8.6 \\
\hline
\end{tabular}

\section{CONCLUSION}

Culvularin and sydowinin B were isolated from the EtOAc extract of the marine sponge derived fungi, $P$. oxalicum (WR3). The compounds showed antibacterial activity with the MICs against S. aureus 125 and 500 $\mu \mathrm{g} /$ disc, respectively and the MIC values against Methicillin-Resistant Staphylococcus aureus 250 and 500 $\mu \mathrm{g} /$ disc, respectively. Culvularin showed higher cytotoxicity against T47D, HeLa, and WiDr cancer cell lines compared to sydowinin B.

\section{ACKNOWLEDGMENT}

The author thanks the Directorate General of Higher Education, Ministry of National Education, Indonesia, for supporting research funding under the name Fundamental Research project, number T/20/UN.16.17/PT.01.03/AMD/PD-Kesehatan/2020.

\section{REFERENCES}

1. R.W.M. Van Soest, Netherlands Journal of Sea Research, 23(2), 223(1989), DOI:10.1016/00777579(89)90016-1

2. Y.K. Lee, J.H. Lee, H.K. Lee, Journal of Microbiology, 39(4), 254 (2001)

3. Z. Li. Marine Drugs, 7(2), 113(2009), DOI:10.3390/md7020113

4. T.S. Bugni, C.M. Ireland, Natural Product Reports, 21(1), 143(2004), DOI:10.1039/B301926H

5. P. Pruksakorn, M. Arai, N. Kotoku, C. Vilchèze, A.D. Baughn, P. Moodley, W.R. Jacobs Jr, M. Kobayashi, Bioorganic \& Medicinal Chemistry Letters, 20(12), 3658(2010), DOI: 10.1016/j.bmcl.2010.04.100

6. M.A. Artasasta, Yanwirasti, M. Taher, A. Djamaan, D. Handayani, Rasayan Journal of Chemistry, 12(3), 1463(2019), DOI:10.31788/RJC.2019.1235284

7. D. Handayani, T. Wahyuningsih, Rustini, M.A. Artasasta, A.E. Putra and P. Proksch, Rasayan Journal of Chemistry, 13(1), 327(2020), DOI:10.31788/RJC.2020.1315589

8. D. Handayani, R.A. Putri, F. Ismed, T. Hertiani, N.P. Ariantari, P. Proksch, Rasayan Journal of Chemistry, 13(1), 417(2020), DOI:10.31788/RJC.2020.1315517

9. D. Handayani, R.F. Ahdinur, R. Rustini. Journal of Applied Pharmaceutical Science, 5(10), 154(2015), DOI: 10.7324/JAPS.2015.501027

10. D. Handayani, W. Rasyid, Rustini, E.N. Zainudin, T. Hertiani. Journal of Applied Pharmaceutical Science, 8(01), 055(2018), DOI:10.7324/JAPS.2018.8109

11. J. Kjer, A. Debbab, A.H. Aly, and P. Proksch. Nature Protocols, 5(3), 479(2010), DOI: 10.1038 nprot.2009.233

12. A. Bahuguna, I. Khan, V.K. Bajpai, and S.C. Kang. Bangladesh Journal of Pharmacology, 12(2), 115 (2017), DOI:10.3329/bjp.v12i2.30892

13. K. Meusemann, B.M. von Reumont, S. Simon, F. Roeding, S. Strauss, P. Kuck, I. Ebersberger, M. Walzl, G. Pass, S. Breuer, V. Achter, A. von Haeseler, T. Burmester, H. Hadrys, J.W. Wagele, B. Misof. Molecular Biology and Evolution, 27(11), 2451(2010), DOI:10.1093/molbev/msq130

14. K.M. Meepagala, R.D. Johnson, and S.O. Duke. Journal of Agricultural Chemistry and Environment, 5, 12(2016), DOI:10.4236/jacen.2016.51002

15. H. Raistrick, F. Rice, Journal of the Chemical Society C: Organic, 18, 3069(1971).

16. A. Kobayashi, T. Hino, S. Yata, T.J. Itoh, H. Sato, K. Kawazu, Agricultural and Biological Chemistry. 52(12), 3119(1988), DOI:10.1271/bbb1961.52.3119

17. D.J. Robeson, G.A. Strobel, Zeitschrift für Naturforschung C, 36(11-12), 1081(1981)

18. A. Little, and J.A. Porco Jr. Organic Letters, 14(11), 2862(2012), DOI:10.1021/o1301107m

19. T. Hamasaki, Y. Sato, Y. Hatsuda, Agricultural and Biological Chemistry, 39(12), 2341(1975). 
RASĀYAN J. Chem.

Vol. 13 | No. 3 |1817-1823| July - September | 2020

20. K. Trisuwan, V. Rukachaisirikul, M. Kaewpet, S. Phongpaichit, N. Hutadilok-Towatana, S. Preedanon, J. Sakayaroj, Journal of Natural Products, 74(7), 1663(2011), DOI:10.1021/np200374j

21. Q. Yao, J. Wang, X. Zhang, X. Nong, X. Xu, S. Qi, Marine Drugs, 12(12), 5902(2014), DOI: $10.3390 / \mathrm{md} 12125902$

22. Y. Tian, X. Qin, X. Lin, K. Kaliyaperumal, X. Zhou, J. Liu, Z. Ju, Z. Tu, Y. Liu, The Journal of Antibiotics, 68(11), 703(2015), DOI:10.1038/ja.2015.55

23. M.S. Elnaggar, S.S. Ebada, M. Ashour, L. Ebrahim, W.E. Müller, A. Mándi, T. Kurtán, A. Singab, W. Lin, Z. Liu, Tetrahedron, 72(19), 2411(2016), DOI:10.1016/j.tet.2016.03.073

24. J. Bao, F. He, J.-H. Yu, H. Zhai, Z.-Q. Cheng, C.-S. Jiang, Y. Zhang, Y. Zang, X. Zhang, G. Chen, H. Zang, Molecules, 23(8),1982 (2018), DOI:10.3390/molecules23081982

25. D. Lai, H. Brötz-Oesterhelt, W.E. Müller, V. Wray, P. Proksch, Fitoterapia, 91, 100(2013), DOI: $10.1016 /$ j.fitote.2013.08.017

26. A.H. Aly, A. Debbab, R.A. Edrada-Ebel, W.E.G. Müller, M.H.G. Kubbutat, V. Wray, R. Ebel, P. Proksch, Mycosphere, 1, 153 (2010)

27. S.J. Jiang, S. Qiang, Y.Z. Zhu, Y.F. Dong, Annals of Applied Biology, 152(1), 103(2007), DOI: $10.1111 / \mathrm{j} .1744-7348.2007 .00202 . x$

[RJC-5549/2020] 